\title{
The Ross Orogen and Lachlan Fold Belt in Marie Byrd Land, Northern Victoria Land and New Zealand: Implication for the tectonic setting of the Lachlan Fold Belt in Antarctica
}

\author{
J D Bradshaw
}

Department of Geological Sciences, University of Canterbury, Christchurch, New Zealand.

\begin{abstract}
Correlation of the Cambrian Delamerian Orogen of Australia and Ross Orogen of the Transantarctic Mountains widely accepted but the extension of the adjacent Lachlan Orogen into Antarctica is controversial. Outside the main Ross-Delamerian belt, evidence of this orogeny is preserved at Mt Murphy in Marie Byrd Land and the in Takaka Terrane of New Zealand. In all pre-break- configurations of the SW Pacific, these two areas are far removed from the Ross-Delamerian belt. Evidence from conglomerates in the Takaka Terrane, however, shows that in Late Cambrian times it was adjacent to the Ross Orogen. This indicates major tectonic displacements within Gondwana after the Cambrian and before break-up. The Lachlan Orogen formed in an extensional belt in a supra-subduction zone setting and the Cambrian rocks of Marie Byrd Land and New Zealand are interpreted as parts of a rifted continental ribbon on the outboard side of the Lachlan belt.

Citation: Bradshaw, J.D. (2007), The Ross Orogen and Lachlan Fold Belt in Marie Byrd Land, Northern Victoria Land and New Zealand: Implication for the tectonic setting of the Lachlan Fold Belt in Antarctica, in Antarctica: A Keystone in a Changing World - Online Proceedings of the 10th ISAES, edited by A.K. Cooper and C.R. Raymond et al., USGS Open-File Report 2007-1047, Short Research Paper 059, 4 p.; doi:10.3133/of2007-1047.srp059
\end{abstract}

\section{Introduction}

The Delamerian Orogen of Australia and the Ross Orogen of the Transantarctic Mountains are widely accepted as parts of a single Cambrian belt separated by Late Mesozoic continental break-up (Flöttmann et al., 1993). In south-eastern Australia, the Delamerian Orogen is defined by the distribution of rocks that have undergone multistage Middle to Late Cambrian deformation and Cambrian to earliest Ordovician magmatism (Glen, 2005). The western part is mainly Proterozoic rocks of the Adelaide Fold-Thrust Belt. To the east, the thinned continental margin is overlain by Cambrian sediments that that host granites (Foden et al., 2006). In the Transantarctic Mountains, Proterozoic to Early Cambrian sediments and metasediments are cut by numerous Cambrian granitoids of the Granite Harbour Intrusives (Stump, 1995). Overall the pattern is very similar to that in Australia and supports the correlation. Further to the south in the Central Transantarctic Mountains and continuing to the Weddell Sea, the pattern and chronology of deformation differs in detail as might be expected to an orogen more than $3500 \mathrm{~km}$ long. Deformation and magmatism suggests an active continental margin arc driven by subduction (Rocchi et al., 1998; Allibone and Wysoczanski, 2002; Foden et al., 2006).

Evidence of Ross-Delamerian deformation and metamorphism has been presented from New Zealand (Gibson and Ireland, 1996; Jongens et al., 2003) and from eastern Marie Byrd Land, where igneous and metamorphic rocks with typical Ross ages have been reported (Pankhurst et al., 1998). When the results of Cretaceous crustal extension and continental break-up are removed, both these regions remain more than $1000 \mathrm{~km}$ away from the main Ross-Delamerian belt (Fig 1).

Western Tasmania also has typical Delamerian deformation and magmatism (Glen, 2005) but there is debate about location of Tasmania in the Cambrian (see Meffre et al., 2000; Gray and Foster, 2004; Squire and Wilson, 2005).

\section{Ross-Delamerian accreted terranes}

Cambrian arc terranes that were accreted to the continental margin-arc are recognised in northern Victoria Land and New Zealand. In northern Victoria Land Cambrian igneous and metamorphic rocks of continental margin type are bordered on their eastern side by the Bowers Terrane, an arc to back-arc assemblage of marine sedimentary and volcanic rocks with oceanic affinities (Weaver et al., 1984; Rocchi et al., 1998). In the Late Cambrian, the back-arc basin was in-filled with thick, coarse, marine and fluvial syntectonic conglomerate derived from both the volcanic arc and from the Ross continental margin-arc, demonstrating Cambrian accretion(Weaver et al., 2003).

Cambrian rocks of Takaka Terrane in New Zealand (Fig. 1) comprise a marine arc to back-arc assemblage with oceanic affinities (Münker and Cooper, 1999) similar to the Bowers Terrane. Arc development culminated in deformation and the infilling of the backarc with cobble to boulder fluvial conglomerates. Recently, Gutjahr et al. (2006) have shown that these conglomerates include Precambrian sandstone and continental margin-arc type granitoids of RossDelamerian age. Their data suggests that the Takaka Terrane was accreted to the Ross-Delamerian orogen in the Late Cambrian. In detail, the Bowers terrane and Takaka terrane rocks and events are remarkably similar and close proximity of the two terranes in the Cambrian is strongly indicated. Thus, in contrast to the Bowers terrane, which still lies near its site of accretion, the of post Cambrian tectonic displacement that pre-dates Mesozoic continental break-up tectonics. 


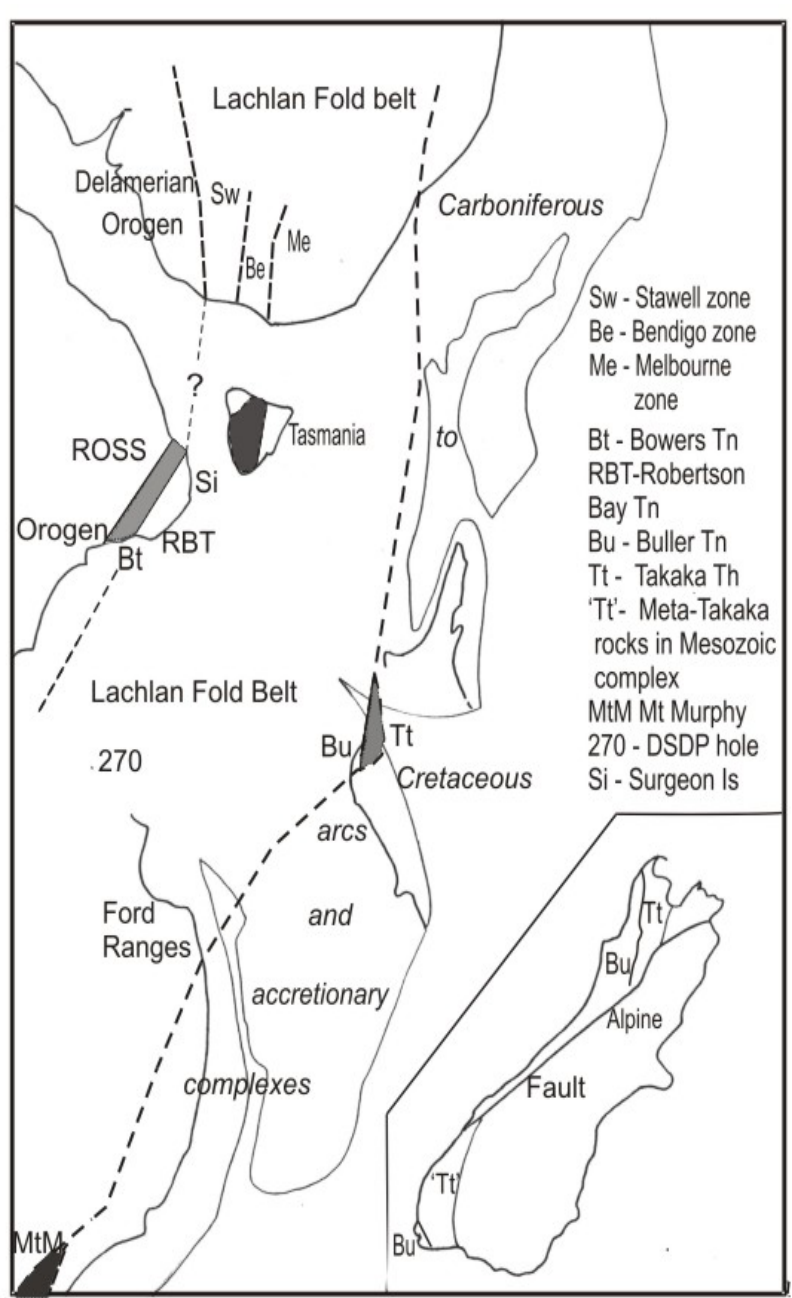

Figure 1. Distribution of Early Paleozoic tectonic elements in the Mesozoic configuration of Gurnis and Muller (2003). Mid-grey areas are Cambrian accreted oceanic arc rocks. Dark grey areas are displaced Ross continental arc rocks. Inset: Distribution of Buller and Takaka terranes in the South Island after Cenozoic dextral displacement and shortening along the Alpine Fault sector of the Australia-Pacific plate boundary.

The Ross-Delamerian correlatives of eastern Marie Byrd Land form part of the basement of the Cenozoic Mt Murphy volcano. The oldest rocks include metasediments, metabasites, and granitic orthogneiss. Zircons within the orthogneiss suggest a Ross-Delamerian crystallization age of $505 \pm 5 \mathrm{Ma}$ and data from the associated paragneiss is also consistent with a RossDelamerian origin (Pankhurst et al., 1998; Mukasa and Dalziel, 2000).

Other evidence of displaced Ross-Delamerian basement includes the metamorphic rocks of DSDP site 270 (Ford and Barrett, 1978) in the central Ross Sea and the granite of Surgeon Island in Yule Bay (eastern extremity of the Robertson Bay Terrane). This granite has a typically Ross in age of 511.7 \pm 2.9 (Fioretti et al., 2005).
Like site 270and Mt Murphy, it may represent a more internal zone of the orogen than the Bowers or Takaka terranes. Evidence from Re-Os isotopes (Handler et al., 2003) suggests other fragments of Cambrian or older rocks may exist within the crust below Marie Byrd Land and Glen (2005) cites a detached fragment of the Delamerian fore-arc in eastern New South Wales.

\section{The Lachlan Fold Belt}

The Lachlan Fold Belt lies to the east of the Delamerian Orogen in Australia; Gray and Foster (2004) and Glen (2005) concur in the view that the belt formed between the Ordovician to Carboniferous during a period marked by protracted subduction zone retreat and crustal extension, punctuated by short periods of contraction (see also Gray et al., 2006). The supra-subduction zone setting is supported by the abundant magmatism during its development. The fold belt can be divided into a number of north-south trending tectonic zones (Vandemberg et al., 2000). The three western zones (Stawell, Bendigo and Melbourne) are relevant here and potentially identifiable outside Australia. The Stawell and Bendigo zones are characterized by latest Cambrian to Ordovician flysch successions derived from uplift of the Delamerian orogen and deposited in a basin floored by Cambrian mafic volcanic rocks and arc relics. The flysch was folded in the Late Ordovician Benambran Orogeny at 440-450 Ma ((Vandemberg et al., 2000; Gray and Foster, 2004; Glen 2005). The boundary between the Bendigo zone and the Melbourne zone to the east is marked by a transition to more pelitic sediments and a concordant OrdovicianSilurian succession. The age of the first deformation in the Melbourne zone is Middle Devonian.

Lachlan Fold belt type rocks in Marie Byrd Land are the Swanson Formation, widely exposed in the Ford Ranges (Fig 1). Bradshaw et al., (1983) describe a thick succession of quartzose turbidites typical of submarine fan sedimentation. The rocks are folded into large upright folds with well developed cleavage. Folding and metamorphism between 444 and $448 \mathrm{Ma}$ is indicated (Adams, 2004). The Swanson Formation is cut by Devonian and Mesozoic granitoids.

In New Zealand, rocks with affinities to the western Lachlan Fold Belt occur in the Buller Terrane to the west of the Cambrian arc volcanic rocks of the Takaka Terrane. West of the Devonian Karamea Batholith, the Greenland Group has similar lithology, structure and metamorphic ages to those of the Swanson Formation (Adams, 2004). East of the Karamea Batholith Greenland Group rocks are overlain by quartzite and thick graptolitic mudstone units that range up to the Late Ordovician and abut the boundary with the Takaka Terrane. There is, however, no evidence of Late Ordovician deformation and both side of the terrane boundary show the same pattern of Middle Devonian deformation (Jongens, 2006). This eastward change in succession and the loss of Late Ordovician deformation resembles the situation in the 
boundary zone between the Bendigo and Melbourne zones in Victoria.

The Robertson Bay Group (Robertson Bay Terrane) in northern Victoria Land closely resembles the Swanson Formation (Bradshaw et al., 1983) but they were not correlated because of a supposed difference in age. The Robertson Bay Group was considered to be Precambrian to Cambrian in age until conodonts and trilobites were found in an allochthonous block of limestone in an olistostrome within the Handler Formation (Burrett and Findlay, 1984; Wright et al., 1984). The fossils indicate an age near the Cambrian-Ordovician boundary and show that at least part of the Robertson Bay Group could be Ordovician. Wright and Brodie (1987) concluded that the Handler Formation was the youngest part of the Robertson Bay Group and that most of the Group was Cambrian. While it is true that the Handler Formation locally overlies normal Robertson Bay type rocks, in the absence of a clear picture of the structure of the terrane as a whole, and with the presence of both low angle thrusts and younger reverse faults immediately to the west (Findlay, 1992), it is hard to be certain whether these rocks are near the top or the bottom of the Group.

Many papers treat the Robertson Bay Terrane as part of the Ross Orogen and interpret the geochronology as evidence of a young Ross deformation. The results of attempts to date the folding of the Robertson Bay Group by K-Ar (Adams and Kreuzer, 1984) and Ar-Ar methods (Dallmeyer and Wright, 1992) are ambiguous. Both systems produce an eastward younging pattern of dates, with ages up to $508 \mathrm{Ma}$ close to the fossiliferous rocks. In relation to modern time-scales, these ages are older than the depositional age indicated by the fossils by a minimum of 3\%. As Adams (2004) notes, these old ages may be the result surviving detrital mineral ages and the scavenging of radiogenic argon from other sources. This problem may well affect the whole data set and is unwise to continue to regard these ages as evidence of young events in the Ross Orogeny. The Robertson Bay Terrane is more likely related to the western Lachlan Fold Belt, where an eastward younging pattern of metamorphic ages is also typical, but with the northern Victoria Land ages $5-10 \%$ too old. Detrital zircon ages from the Robertson Bay Group show the usual Gondwana margin pattern with a dominant contribution from eroded Ross-Delamerian sources (T. R. Ireland pers.comm.). Correlation of the Robertson Bay Terrane and parts of the Lachlan Fold Belt is implicit in some published maps (e.g. Flöttmann et al., 1993) but does not seem to be accepted by many in the Antarctic community (e.g.Tessensohn and HenjesKunst, 2005; Fioretti et al., 2005).

\section{Conclusions}

Identification of the Robertson Bay Group as a latest Cambrian-Ordovician correlative of the Swanson Formation, the Greenland Group, and the Stawell Zone of Victoria simplifies and clarifies the relationship of Ross
Delamerian and Lachlan Orogens in Antarctica. The latter formed by deformation of rocks from a wide belt of supra-subduction zone extension that continued southward from Australia across the Ross Sea region into Marie Byrd Land. Small differences that exist between these thick turbidite piles are consistent with the existence of a number of related submarine fans (Glen, 2005). Rifted relics of Ross-Delamerian arc rocks occur near the eastern margin of this belt in New Zealand, eastern Marie Byrd Land, and possibly within the belt, at DSDP site 270 in the Ross Sea and Surgeon Island. The style of tectonic development seen in the Lachlan Fold Belt in Australia continued into the Ross Sea region and Marie Byrd Land. The south eastern limit of the Lachlan Fold Belt is not known although evidence of Late Cambrian-Early Ordovician extensional tectonics in the Pensacola Mountains (Curtis et al., 2004), near the Weddell Sea, suggests that the belt probably crosses the Antarctic continent.

Acknowledgments. Comments from Kari Bassett and Bryan Storey improved this paper.

\section{References}

Adams, C. J. (2004), Rb-Sr age and strontium isotopic characteristics of the Greenland Group, Buller Terrane, New Zealand, and correlations at the East Gondwana margin, N. Z. J. Geol. Geophys., 47, 189-200.

Adams, C.J., and H. Kreuzer (1984), Potassium-argon age studies of slates and plyllites from the Bowers and Robertson Bay terranes, north Victoria Land, Antarctica, Geol. Jahrbuch B60, 265-288.

Allibone, A.H., and R. Wyscozanski (2002), Initiation of magmatism during Cambrian-Ordovician Ross Orogeny in southern Victoria Land, Geol. Soc. America Bulletin, 114, 1007-1018.

Bradshaw, J.D., P. B. Andrews, and D. B. Field (1983), Swanson Formation and related rocks of Marie Byrd Land and comparison with the Robertson Bay Group of north Victoria Land, in Antarctic Earth Science, edited by R. L. Oliver, P. R. James and J. B. Jago, pp. 274-79, Australian Academy of Science, Canberra.

Burrett, C.F., and R. H. Findlay, R.H. (1984), Cambrian and Ordovician conodonts from the Robertson Bay Group, Antarctica, and their tectonic significance, Nature, 307, 723-726.

Curtis, M. L., I. L. Millar, B. C. Storey, and M. Fanning (2004), Structural and geochronological constraints on early Ross orogenic deformation in the Pensacola Mountains, Antarctica, Geol. Soc. America Bulletin, 116, 619-636.

Dallmeyer, R. D., and T. O. Wright (1992), Diachronous cleavage development in the Robertson Bay Terrane, northern Victoria Land, Antarctica: tectonic implications, Tectonics, 11, 437-448.

Findlay, R. H. (1992), The age of cleavage development in the Ross orogen, northern Victoria Land, Antarctica: evidence from $\mathrm{Ar} / \mathrm{Ar}$ whole rock slate ages, J. Struct. Geol.,14, 887-890.

Fioretti, A., G. Capponi, L. P. Black, R. Varne and D. Visona (2005), Surgeon Island granite SHRIMP zircon ages: a clue for the Cambrian tectonic setting and evolution of the Paleopacific margin of Gondwana (northern Victoria Land, Antarctica), Terra Nova, European J. Geosciences, 17, 242-249.

Flöttmann, T., G. M. Gibson, and G. Kleinschmidt (1993), Structural continuity of the Ross and Delamerian orogens of Antarctica and Australia along the margin of the paleo-Pacific, Geology, 21, 319322.

Foden, J. D., M. A. Elburg, J. Dougherty-Page, and A. Burtt (2006), The timing and duration of the Delamerian Orogeny: correlation with the Ross Orogen and implications for Gondwana assembly, J. Geology, 114, 189-210.

Ford, A. B., and P. J. Barrett (1975), Basement rocks of the southcentral Ross Sea, Site 270, in Initial reports, Deep Sea Drilling 
Project, 28, p. 861-868, edited by D. E. Hayes, U.S Government Printing Office, Washington.

Gibson, G. M., and T. R. Ireland (1996), Extension of Delamerian (Ross) orogen into western New Zealand - evidence from zircon ages and implications for crustal growth along the Pacific margin of Gondwana, Geology, 24, 1087-1090.

Glen, R.A. (2005), The Tasmanides of eastern Australia, in Terrane processes at the margin of Gondwana, edited by A. M. P. Vaughan, P. T. Leat, and R. J. Pankhurst, pp. 23-93, Special Publication 246, Geol. Soc. London, Bath.

Gray, D.R., and D. A. Foster (2004), Tectonic evolution of the Lachlan Orogen, southeast Australia: historical review, data synthesis and modern perspectives, Australian J. Earth Sci. 51, 772-817.

Gray, D.R., C. E. Willman, and D D Foster (2006), Crustal restoration for the western Lachlan Orogen using the strian reversal, area balancing technique: implcations for crustal components and original thickness. Australian J.Earth Sci.53, 329-341.

Gurnis, M., and R. D. Muller (2003), Origin of the Antarctic-Australian disturbance from an ancient slab and mantle wedge, in Evolution an dynamics of the Australia Plate edited by R. R. Hillis, R. D. Muller, pp. 417-429. Geol. Soc. America Special Paper 372, Boulder.

Gutjahr, M., J. D. Bradshaw, S. D. Weaver, C. Münker, and T. R. Ireland (2006), Provenance of Cambrian conglomerates from New Zealand: implications for the tectonomagmatic evolution of the SE Gondwana margin, J. Geol. Soc. London, 163, 997-1010.

Handler, M. R., R. J. Wysoczanski, and J. A. Gamble (2003), Proterozoic lithosphere in Marie Byrd Land, West Antarctica: Re-Os systematics of spinel peridotite xenoliths, Chemical Geology, 196, 141.

Jongens, R. (2006), Structure of the Buller and Takaka Terrane rocks adjacent to the Anatoki Fault, northwest Nelson, New Zealand, N.Z. J. Geol. Geophys., 49, 443-461.

Jongens, R., J. D. Bradshaw, and A. Fowler, A. (2003), The Balloon Mélange, northwest Nelson: origin, structure, and emplacement, N. Z. J. Geol. Geophys., 46, 437-448.

Meffre, S., R. F. Berry, and M. Hall M. (2000), Cambrian metamorphic complexes in Tasmania: tectonic implications, Australian J. Earth Sci., 47, 971-985.

Mukasa, S. B., and Dalziel, I.W.D. 2000, Marie Byrd Land, West Antarctica: Evolution of Gondwana's Pacific margin constrained by zircon U-Pb geochronology and feldspar common- $\mathrm{Pb}$ isotopic compositions, Geol. Soc. America Bulletin, 112, 611-627.

Münker, C., and R. A. Cooper (1999), The Cambrian arc complex of the Takaka Terrane, New Zealand: an integrated stratigraphical, paleontological and geochemical approach, N. Z. J. Geol. Geophys., 42, 415-445.

Pankhurst, R.J., S. D. Weaver, J. D. Bradshaw, B. C. Storey, and T. R. Ireland, T.R. (1998), Geochronology and geochemistry of preJurassic superterranes in Marie Byrd Land, Antarctica, J. Geophys. Res, 103, 2529-2547.

Rocchi, S., S. Tonarini, P. Armienti, F. Innocenti, and P. Manetti (1998), Geochemical and isotopic structure of the early Palaeozoic active margin of Gondwana in northern Victoria Land, Antarctica, Tectonophysics, 284, 261-281.

Squire, R.J., and C. J. L.Wilson (2005), Interaction between collisional orogenesis and convergent-margin processes: evolution of the Cambrian proto-Pacific margin of East Gondwana, J. Geol. Soc. London, v. 162, p. 749-761.

Stump, E. (1995), The Ross Orogen of the Transantarctic Mountains, Cambridge University. Press, Cambridge, $284 \mathrm{p}$.

Tessensohn, F., and F. Henjes-Kunst (2005), Northern Victoria Land terranes, Antarctica: far-travelled or local products, in Terrane Processes on the margins of Gondwana, edited by A. M. P. Vaughan, P. T. Leat, and R. J. Pankhurst, pp.275-291, Special Publication 246, Geol. Soc. London, Bath.

Vandenberg, A.H.M., C. E. Willman, S. Maher, B. A., Simons, R. A. Cayley, D. A. Taylor, and A. Radojkovic (2000), The Tasman Fold belt in Victoria, Geol. Surv. Victoria, Melbourne, $462 \mathrm{p}$.

Weaver, S. D, K. Bassett, J D Bradshaw,. and T. R. Ireland (2003), Accretion of the Cambrian Bowers terrane arc to the Gondwana margin, northern Victoria Land: evidence from conglomerate provenance, in 9th International symposium on Antarctic earth science edited by Futterer, D.K., Potsdam, Alfred Wegener Stiftung., p. 335-336.

Weaver, S. D., J. D. Bradshaw, and M. G. Laird (1984), Geochemistry of Cambrian volcanics of the Bowers Supergroup and implications for the early Palaeozoic tectonic evolution of northern Victoria Land, Antarctica, Earth and Planetary Science Letters, 68, 128-140.

Wright, T. O. and C. Brodie (1987), The Handler Formation, a new unit of the Robertson Bay Group, northern Victoria Land, Antarctica, in Gondwana Six: Structure, tectonics and Geophysics, edited by McKenzie, G.D. pp. 25-29. Monograph 40, American Geophys. Union, Washington.

Wright, T. O., R. J. Ross, and J. E. Repetski (1984), Newly discovered youngest Cambrian or oldest Ordovician fossils from the Roberson Bay terrane (formerly Precambrian), northern Victorian land, Antarctica, Geology, 12, 301-305. 